\title{
Comparative Study on the Effects of Phenyl Boron and Boric Acid on the Development and Gene Expression (Connexin X43 and E-Cadherin) of Pre- implantationBovine Embryos \\ *Asmaa M Kandil, **Rings F, **Tesfaye D, **Hölker M, **Schellander K \\ *Department of pharmacology National Organization for Drug Control and Research. \\ **Institute of Animal Science, Animal Breeding and Husbandry group Bonn University, Germany.
}

\begin{abstract}
The different actions of Boron (as Phenyl boron (PB) or Boric acid (BA)) on the growth of preimplantation embryos and their (Connexin X43(CX43) and E-Cadherin) gene expression was investigated. In the first and two experiments, phenyl boron or boric acid was added as 0, 20 and 250 $\mu \mathrm{M} / \mathrm{L}$ in embryo culture medium at 18-20 h after in-vitro fertilization (IVF). The percentage of development to blastocyst stage was assessed from day 7 to day 9 post treatment. The experiment was repeated two times using 50 fertilized zygotes /treatment.

The total of two of 10 blastocysts pools from each treatment group was used for mRNA isolation for quantification of $\mathrm{Cx} 43$ and E-cadherin gene mRNA, in the embryos of each treatment group was assessed by real time quantitative PCR.

The results indicated that the rate of development to blastocyst is higher in blastocysts group treated with PB than that of BA. The highest development rate was at the $20 \mu \mathrm{M} / \mathrm{L}$ PB and the lowest was at the $20 \mu \mathrm{M} / \mathrm{L}$ BA treatment. The development of zygotes treated with $250 \mu \mathrm{M} / \mathrm{L}$ BA was arressted at 4cell stage then they degenerated.

Relative expression levels of CX 43 were very high at doses of $250 \mu \mathrm{M} / \mathrm{L}$ PB and $20 \mu \mathrm{M} / \mathrm{L}$ BA while at the same doses the relative expression levels of E-cadherin were very low.
\end{abstract}

\section{Introduction}

Boron is one of at least 150 different minerals of the earth's crust and is readily Transported into top soil, water and air (Nemodruk and Karalova 1969 \& Basset 1990). Agricultural soil boron concentrations range from 0.6 to $7.4 \mathrm{mM}$ (Stevenson 1986); in rain water it varies from $0.4 \mu \mathrm{mol} / \mathrm{L}$ in rain $(\mathbf{F o g g}$ and Duce 1985, Libes 1992), to $1.7 \mu \mathrm{mol} / \mathrm{L}$ in fresh water rivers and lakes to $420 \mu \mathrm{mol} / \mathrm{L}$ in the ocean (Basset 1990).

Douglas et al.,(1999) reported that exposure of adult Xenopus laevis and embryos to a low boron(B) environment is capable of inducing impaired reproductive performance, abnormal organogenesis and increased embryo lethality and abnormal development of the gut (Fort et al., 1999). The early stage of embryo development is especially sensitive to $\mathrm{B}$ deficiency as described for mated zebrafish ( Rowe et al. 1998 and Rowe and Eckhert, 1999) and the preimplantation mouse embryo (Lanoue et al. 1999 ).
The bovine preimplantation embryogenesis is characterized by various morphological and physiological changes that occur following fertilization. These developmental events include the first cleavage division, the timing of which is known to be an indicator of the activation of embryonic genome (Memili

et al., 1998), subsequent developmental potential of the embryo (Lonergan et al., 1999) as compaction of morula, and formation of blastocyst. These morphological and physiological transitions are known to be accompanied and regulated by differential expression of organogenesis genes (Zimmermann and Schultz, 1994; Schultz et al., 1999).

It has been demonstrated that while oocyte quality is the main determinant of the blastocyst development rate in vitro, the post fertilization culture conditions are the main factors affecting the quality of the resulting blastocysts as measured in terms of 


\section{Comparative Study on the Effects of.....}

cryotolerance and relative transcript abundance (Rizos et al., 2002a,b, 2003; Lonergan et al., 2003a,b).

Gap junctions maintain cellular homeostasis by allowing communication between adjacent cells. They span the plasma membrane of two adjacent cells (Makowski $\boldsymbol{e t}$ al. 1977), with each cell contributing half the channel; a hemi channel, or connexon. A connexon from one cell docks in the extra cellular space with a connexon from an opposing cell to form a complete gap-junction channel, allowing adjacent cells to be coupled (reviewed by Bruzzone et al. 1996a). Each connexon is multimeric assemblies of six proteins, termed connexins .Connexins are integral membrane proteins containing four transmembrane, two extracellular and three intracellular domains. Connexins are classified according to their molecular mass (Beyer et al. 1987). For example, connexin $(\mathrm{Cx} 43)$ has a predicted molecular mass of $43 \mathrm{kDa}$ and $\mathrm{Cx} 31$ has a predicted molecular mass of $31 \mathrm{kDa}$. Co expression of connexins is common; hepatocytes express both $\mathrm{Cx} 26$ and Cx32 (Nicholson et al. 1987), as do proximal kidney tubule cells (Butterweck et al. 1994), whereas vascular endothelium co-expresses Cx37 and Cx40 (Delorme et al. 1997). Gap junctions may be regulated by hormones and other extracellular signaling molecules such as neurotransmitters, growth factors and cytokines (Stagg \& Fletcher 1990, Bruzzone et al. 1996b, Sa'ez et al. 1998). The extent to which cells are coupled depends on several mechanisms: gene transcription, stability of the message, translational and posttranslational modifications and assembly of the protein into the membrane (Sa'ez et al. 1998).

Endothelial cell-cell adhesive junctions are formed by transmembrane adhesive proteins linked to a complex cytoskeletal network. These structures are important not only for maintaining adhesion between endothelial cells and, as a consequence, for the control of vascular permeability, but also for intracellular signaling properties. The establishment of intercellular junctions might affect the endothelial functional phenotype by the down regulation or up regulation of endothelial- specific activities (Lampugnani and Dejana 1997).

E-cadherin is a calcium-dependent cell adhesion molecule, which belongs to a family of developmental proteins responsible for maintaining the structural integrity of an epithelial monolayer.

E-cadherin is one of the most important molecules in cell-cell adhesion in epithelial tissues. It is localized on the surfaces of epithelial cells in regions of cell-cell contact known as adherens junctions [ Gumbiner,1996] .As a member of a large family of genes coding for calcium-dependent cell adhesion molecules (CAMs), the cadherin glycoproteins are expressed by a variety of tissues, mediating adhesion through homotypic binding. Classical cadherins - Eand $\mathrm{N}$-cadherins being the best characterized play important roles in the formation of tissues during gastrulation, neurulation and organogenesis [Barth,et al.,1997].

The aim of this study is to investigate the effect of phenyl boron (PB) or boric acid (BA) on development of bovine blastocysts and cell-cell adhesive junctions by studying the Gene Expression (Connexin X43 and ECadherin) of Pre-implantation bovine Embryos.

\section{Material and Method}

\section{IVM and IVF of Bovine Oocytes}

Oocyte collection, In-vitro maturation (IVM) and in-vitro fertilization (IVF) were carried out as described by Yoshioka and Kamomae, 1996. Briefly, cumulus-oocyte complexes (COC) were aspirated from small antral follicles $(2-5 \mathrm{~mm}$ in diameter) on bovine ovaries obtained from a slaughterhouse. After washing of COC with Hepes-buffered Tyrode's medium (TALP-Hepes [Tesfaye et al., 2007]), only oocytes with 3-4 layers of intact and unexpanded cumulus cells were selected; these were then cultured for 22 hours (h.) with maturation medium (Hepes-buffered TCM199 [Sigma Chemical Co., St. Louis, $\mathrm{MO}]+10 \%$ heat-inactivated fetal bovine serum [Gibco Life Technologies, Grand Island, NY] supplemented with $0.2 \mathrm{mM}$ sodium pyruvate, $0.02 \mathrm{U} / \mathrm{ml}$ porcine follicular 
stimulating hormone (FSH) [Sigma], $1 \mu \mathrm{g} / \mathrm{ml}$ estradiol-17ß [Sigma], and $50 \mu \mathrm{g} / \mathrm{ml}$ gentamicin sulfate [Sigma] at $39^{\circ} \mathrm{C}$ in a humidified atmosphere of $5 \% \mathrm{CO}_{2}$ in air.

\section{Sperm Capacitation and IVF}

Following in vitro maturation (IVM), COCs were transferred into a 4-well dish containing $400 \mathrm{ml}$ fertilization medium (Fert-TALP, Parrish et al., 1988), which is supplemented with $6 \mathrm{mg} / \mathrm{ml}$ BSA (Sigma), $2.2 \mathrm{mg} / \mathrm{ml}$ pyruvate (Sigma), and $1 \mathrm{mg} / \mathrm{ml}$ Heparin (Sigma). Each milliliter of stock fertilization medium contained $330 \mathrm{mg} \mathrm{NaCl}, 110 \mathrm{mg}$ $\mathrm{CaCl}, 1,050 \mathrm{mg} \mathrm{NaHCO} 3,20 \mathrm{mg} \mathrm{NaPO} 4,30$ $\mathrm{mg}$ penicillin $\mathrm{G}, 50 \mathrm{mg} \mathrm{MgCl} 2,150 \mathrm{mg} \mathrm{CaCl}$. Ten microliters of PHE (penicilinamin, hypotaurin, epinephrin) was added to each well and covered with mineral oil. A swim-up procedure has been applied to obtain motile sperm cells from frozen-thawed semen. The final sperm concentration in fertilization drop was $2 \times 10^{6}$ sperm cells $/ \mathrm{ml}$ cells/ $\mathrm{ml}$. Fertilization was initiated during coincubation of spermatozoa and the matured oocytes for $20 \mathrm{hr}$ in the same incubator under the same temperature and atmospheric $\mathrm{CO} 2$ content as used for maturation.

\section{Embryo culture}

After $20 \mathrm{~h}$ of co incubation with sperm, presumptive zygotes were stripped of cumulus cells by vortex for $4 \mathrm{~min}$ in $1 \mathrm{ml}$ of TALPHepes, and then washed three times with culture medium. zygotes were cultured in groups of up to 50 zygotes in four-well dishes each containing $400 \mathrm{ml}$ CR1 medium (Rosenkranz and First, 1994) until day 7 and 9 after insemination. The CR1 medium is supplemented with $10 \%$ OCS, $20 \mathrm{ml} / \mathrm{ml} \mathrm{BME}$ (amino acids), and $10 \mathrm{ml} / \mathrm{ml}$ MEM (nonessential amino acids) (Gibco BRL, Eggenstein, Germany).

\section{Experimental Design:}

In the first experiment, groups about 45-50 presumptive zygotes were placed at $18-20 \mathrm{~h}$ after insemination in embryo culture medium containing normal medium(CR1), 0(medium free from any traces of boron), 20 and 250 $\mu \mathrm{M} / \mathrm{L}$ PBA (phenyl boron). The experiment was replicated two times using 50 presumptive zygotes /treatment.
In the second experiment the presumptive zygotes were placed at $18-20 \mathrm{~h}$ after insemination in embryo culture medium containing normal medium (CR1), 0 (medium free from any traces of boron), 20 and 250 $\mu \mathrm{M} / \mathrm{L}$ BA (Boric acid). The experiment was replicated two times using 50 presumptive zygotes/ treatment. Development proceeded until day 9 post insemination. In vitro culture was also performed in a humidified atmosphere with $5 \% \mathrm{CO} 2$ at $39 \mathrm{C}$.

The percentages of cleavage, morulae, blastocysts, and hatched blastocysts were calculated within each group. Differences in the mean percentages of cleavage, morulae, blastocysts, and hatched blastocysts among the experimental groups were analyzed by oneway ANOVA.

\section{Embryo Collection}

Morphologically good-quality day 7,8 and 9 blastocysts were used for biopsies, as described in Tesfaye et al. (2004). All embryos were washed two times with PBS (Sigma) and treated with acidic Tyrode $\mathrm{pH}$ 2.5-3 (Sigma) to dissolve the zona pellucida. The zona free embryos were further washed two times in drops of PBS and frozen in cryo tubes containing minimal amounts of lysis buffer [0.8\% Igepal (Sigma), 40 U/ll RNasin (Promega, Mannheim, Germany), $5 \mathrm{mM}$ dithiothreitol (DTT) (Promega)]. Until used for RNA isolation all frozen embryos were stored at $-80^{\circ} \mathrm{C}$.

\section{mRNA isolation and reverse transcription}

A total of two pools of 10 blastocysts from each treatment group were used for mRNA isolation using oligo (dT) attached magnetic beads (Dynal, Norway, Oslo) following the manufacturer's instructions and described by Tesfaye et al. (2003) and (2004).. Briefly, embryos in lysis buffer were mixed with $40 \mathrm{ml}$ binding buffer [20 mM Tris $\mathrm{HCl}, \mathrm{pH} 7.5,1 \mathrm{M}$ $\mathrm{LiCl}, 2 \mathrm{mM}$ ethylene-di-amine-tetra-acetic acid (EDTA), $\mathrm{pH}$ 8.0] and incubated at $65^{\circ} \mathrm{C}$ for $5 \mathrm{~min}$ to obtain complete lysis of the embryo and release of RNA. Ten microlitres of oligo(dT) magnetic bead suspension was added to the samples, and incubated at room temperature for $30 \mathrm{~min}$. The hybridized mRNA and Oligo(dT) magnetic 
beads were washed three times with washing buffer $(10 \mathrm{mM}$ Tris HCL, pH 7.5, $0.15 \mathrm{mM}$ LiCl, 1 mM EDTA, pH 8.0). Finally, mRNA samples were eluted in $12 \mu \mathrm{l}$ DEPC treated water and reverse transcribed in a $20 \mu \mathrm{l}$ reaction volume containing $2.5 \mu \mathrm{M}$ oligo (dT) $12 \mathrm{~N}$ (where $\mathrm{N}=\mathrm{G}, \mathrm{A}$ or $\mathrm{C}$ ) primer, $4 \mu \mathrm{l}$ of $5 x$ first stand buffer $(375 \mathrm{mM} \mathrm{KCl}, 15 \mathrm{mM}$ $\mathrm{MgCl} 2,250 \mathrm{mM}$ Tris- $\mathrm{HCl} \mathrm{pH} 8.3$ ), $2.5 \mathrm{mM}$ of each dNTP, 10 U RNase inhibitor (Promega) and $100 \mathrm{U}$ of SuperScript II reverse transcriptase (Invitrogen, Karlsruhe, Germany). In terms of the order of adding reaction components, mRNA and oligo (dT) primers were mixed first, heated to $70^{\circ} \mathrm{C}$ for 3 min, and placed on ice until the addition of the remaining reaction components. The reaction was incubated at $42^{\circ} \mathrm{C}$ for $90 \mathrm{~min}$, and terminated by heat inactivation at $70^{\circ} \mathrm{C}$ for 15 min.

\section{Quantitative Real-Time PCR}

Quantification of Cx43 and E-cadherin mRNA in the embryos of each treatment group was assessed by real time quantitative PCR. The ABI Prism1 7000 apparatus (Applied Biosystems, Foster City, CA) was used to perform the quantitative analysis using SYBR1 Green JumpStartTM Tag ReadyMixTM (Sigma) incorporation for ds DNA-specific fluorescent detection dye. Quantitative analyses of embryo Cx43 and Ecadherin, cDNA were performed in comparison with heston (H2a) housekeeper gene as an endogenous control (Robert et al., 2002) and were run in separate wells. PCR was performed by using $2 \mu \mathrm{l}$ of each sample cDNA along with specific primers. The primer sequences were designed for PCR amplification according to the bovine cDNA sequence (Table 1) using Primer Express1 Software v2.0 (Applied Biosystems). Standard curves were generated for both target and endogenous control genes using serial dilution of plasmid DNA (101-108 molecules). The PCRs were performed in a $20 \mathrm{ml}$ reaction volume containing $10.2 \mathrm{ml}$ SYBR1 Green universal master mix (Sigma), optimal levels of forward and reverse primers and $2 \mu \mathrm{l}$ of embryonic cDNA. During each PCR, reaction samples from the same cDNA source were run in duplicate to control the reproducibility of the results. A universal thermal cycle (initial denaturation step at $95^{\circ} \mathrm{C}$ for $10 \mathrm{~min}, 45$ cycles of denaturation at $95^{\circ} \mathrm{C}$ for $15 \mathrm{sec}$, and $60^{\circ} \mathrm{C}$ for $60 \mathrm{sec}$ ) was used to quantify each gene of interest. After the end of the last cycle, a dissociation curve was generated by starting the fluorescence acquisition at $60^{\circ} \mathrm{C}$ and taking measurements at $7 \mathrm{sec}$ intervals until the temperature reached $95^{\circ} \mathrm{C}$. Final quantitative analysis was done using the relative standard curve method as used in Tesfaye et al. (2004) and results are reported as the relative expression level compared to the calibrator cDNA after normalization of the transcript amount to the endogenous control.

Table (1) showed the sequences of primers

\begin{tabular}{|l|l|}
\hline Genes & primers \\
\hline Connexin43-623F: & CGTGTGAAGGGAAAGAGCGA \\
\hline Connexin43-808R: & ATTGCGGCAGGAAGAATTGT \\
\hline E-cadrhen-776F: & CCTGATGGTCCAAGCAGCA \\
\hline E-cadrhen -958R: & TCGTCGGCATCAGTCACTGT \\
\hline
\end{tabular}





\section{Results}

Two experiments were conducted in which effects of phenyl (PB) or boric acid (BA) added 18-20 $\mathrm{h}$ after IVF were evaluated (Figs 1-3). In the first experiment, the in-vitro development of bovine embryos was monitored at day 2 to assess the cleavage rate and blastocyst rate was monitored until day 9 during culture in the presence or absence of boron at different formula and concentrations in culture medium.

The effects of phenyl boron addition in culture medium.

When the presumptive zygotes were cultured in the absence of boron, the rate of embryo developement to the stage of morula was $22.41 \%$ less than that of the control and all other groups. But the highest rate of embryo development to morula stage at $7^{\text {th }}$ day after IVF was the embryo cultured in medium with $250 \mu \mathrm{M} / \mathrm{L}$ PBA $(61.54 \%)$.

The rate of blastocyst of presumptive zygotes at $7^{\text {th }}$ day after culture in medium with $20 \mu \mathrm{M} / \mathrm{LPB}$ were very high (38.89) than the control and the lowest rate was that of zygotes in medium with $250 \mu \mathrm{M} / \mathrm{L}$ PB (Fig.1). However the rate of zygotes developed to blastocyst at $8^{\text {th }}$ day was very high in groups cultured in medium with $20 \mu \mathrm{M} / \mathrm{LPB}$ and the lowest rate in group without boron.

Effect s of Boric Acid on the development of presumptive zygotes.

All embryos cultured at high dose of BA $(250 \mu \mathrm{M} / \mathrm{L})$ arrested at four cell stage (fig. 2). There was no effect on the first cleavage rate of zygotes at control, without boron and with $20 \mu \mathrm{M} / \mathrm{L}$ BA groups.

Development to morula and blastocyst stages in control group at $7^{\text {th }}$ and $8^{\text {th }}$ day were high than that of all other groups. In addition the rate of blastocyst in group cultured in mediumwithout boron was more than that in medium with $20 \mu \mathrm{M} / \mathrm{L}$ BA (Fig.3).In the present study

we have different expression patterns in blastocyst at $8^{\text {th }}$ day after cultured in medium as revealed by real time quantitative PCR.

The relative expression of connexin43mRNA in blastocycts treated with $250 \mathrm{uM}$ PBA is very high than blastocyct derived from control medium, without Boron or with $20 \mathrm{uM}$ PB (figure 4).

In the second experiment BA was used. The relative expression of connexin 43 mRNA in blastocyct cultured in medium containing $20 \mathrm{uM}$ BA is very high than the control and than that of medium without BA (figure5). However, the relative expression of connexin 43 mRNA in blastocyct cultured in medium without boron was less than that of the control group.

The relative expression of E-cadherin mRNA in blastocycts cultured in medium with $20 \mathrm{uM}$ $\mathrm{PB}$ is very high than that from medium without PB or with 250uM PB (figure 6).

In the second experiment the relative expression of E-cadherin mRNA in group treated with $20 \mathrm{uM} \mathrm{BA}$ is higher than that in group without boric acid (figure 7).

The results indicate that $\mathrm{PB}$ improved the development of pre-implantation bovine embryo than BA and increased CX43mRNA and E-cadherin mRNA expression of embryo. $\mathrm{PB}$ and $\mathrm{BA}$ high doses were toxic and the absence of $\mathrm{PB}$ or BA decreased blastocyst development of the pre-implantation bovine embryo. 


\section{Comparative Study on the Effects of.....}

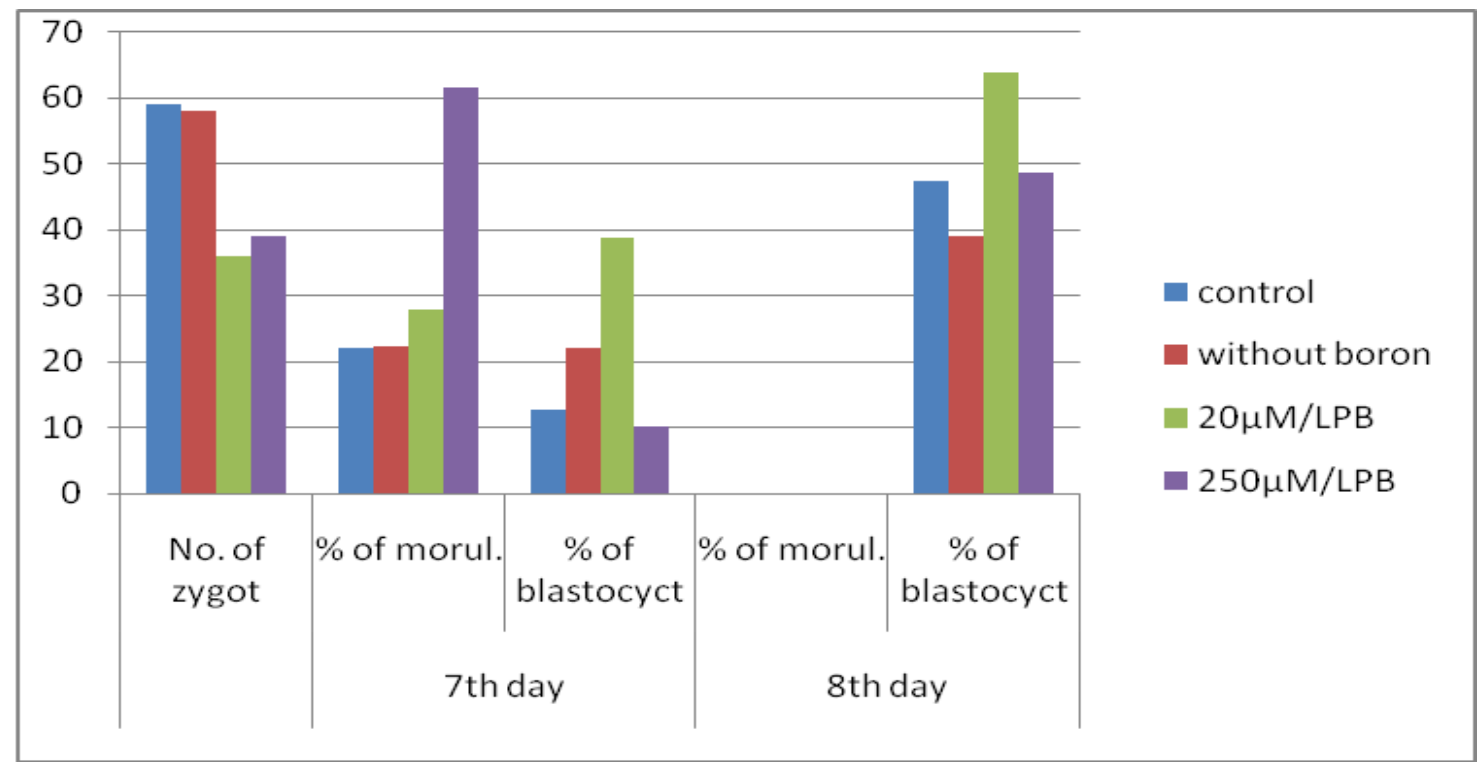

Fig (1) effect of phenyl boron on the rate of the development of pre-implantation bovine embryos

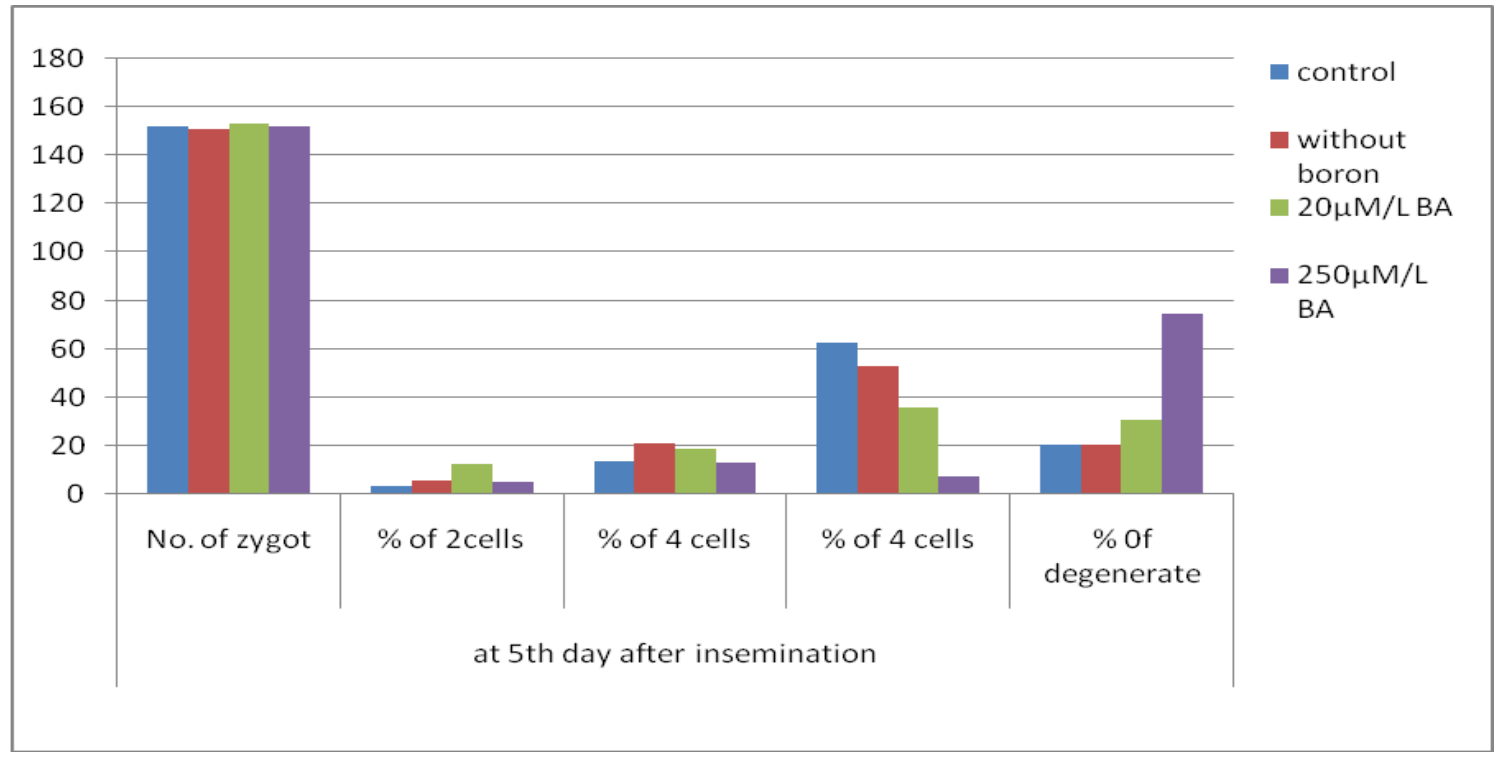

Fig. (2): Effect of Boric acid on the rate of development of pre-implantation bovine embryos at $5^{\text {th }}$ day after In vitro fertilization (IVF) 
Asmaa M Kandil.....

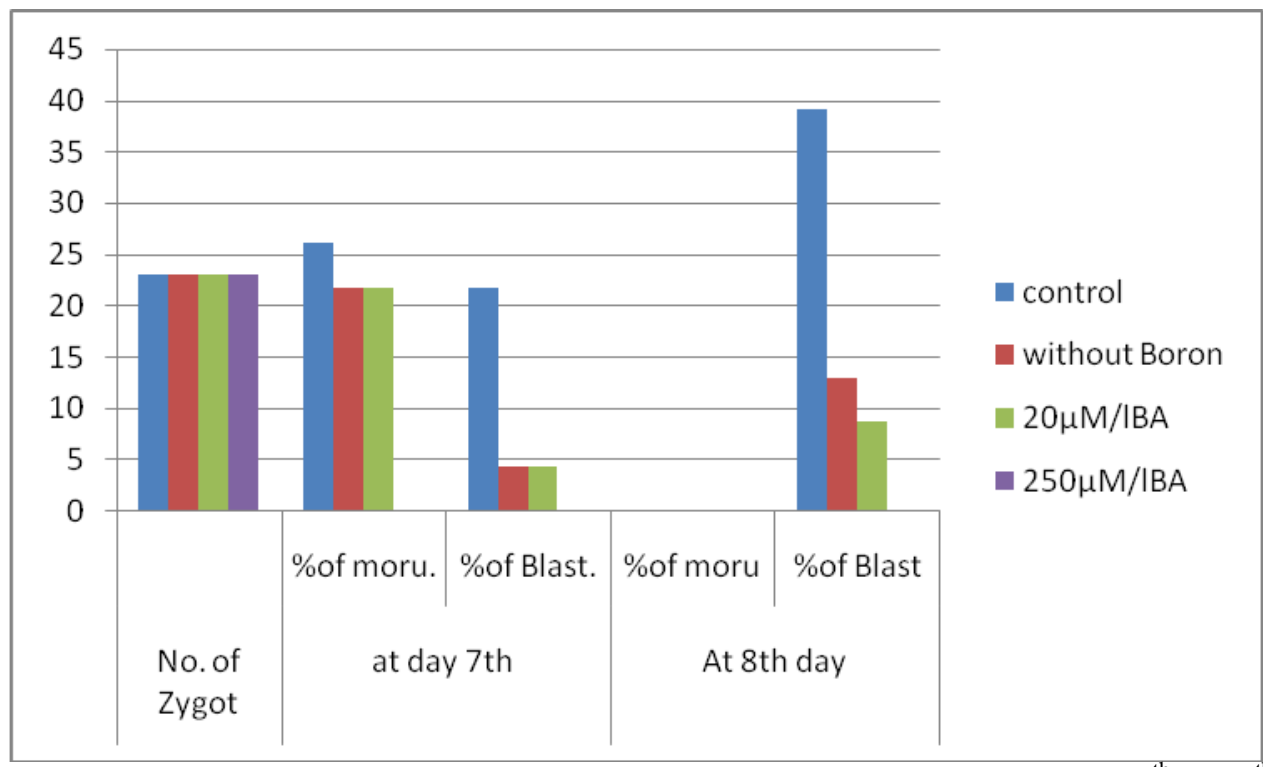

Fig.(3):Effect of Boric acid (BA) on the development of preimplantation bovine embrys at $7^{\text {th }}$ and $8^{\text {th }}$ day after in vitro fertilization (IVF)

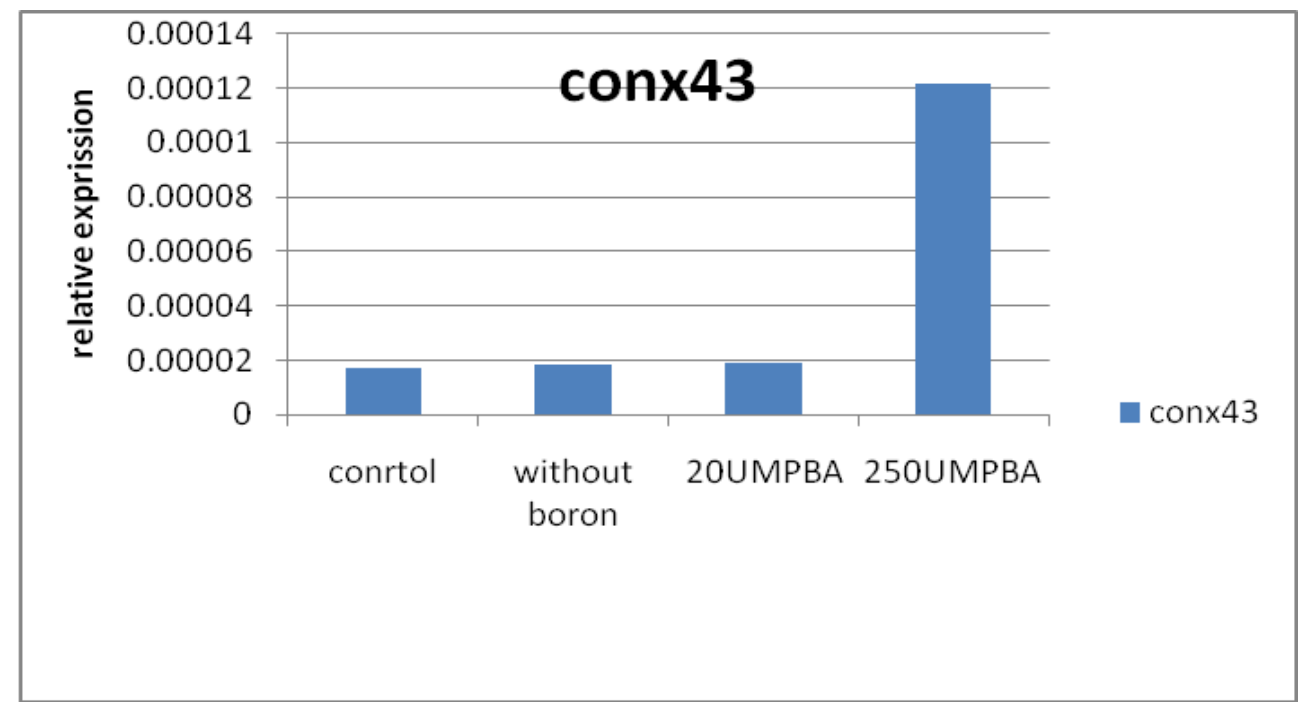

Figure (4): Relative expression level of connexin 43mRNA derived from blastocycts of preimplantation bovine embryo of groups treated with phenyl boron. 


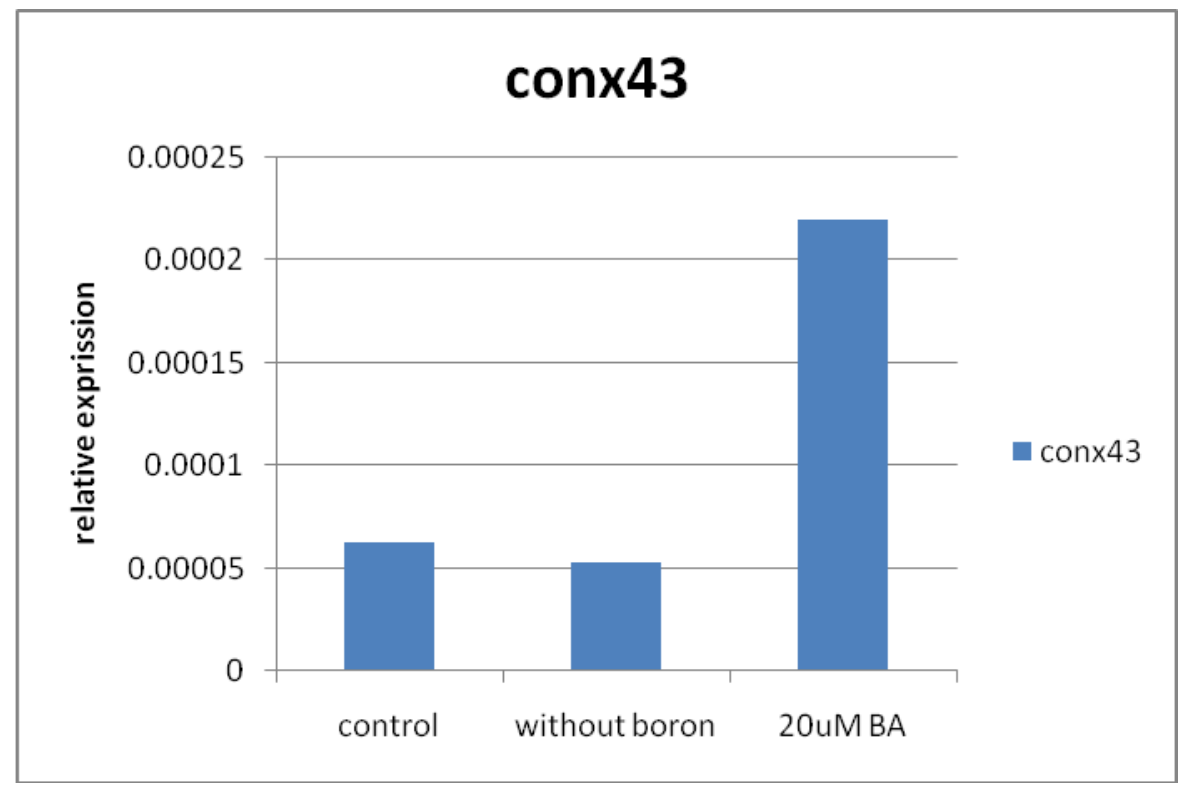

Figure (5): Relative expression level of connexin $43 \mathrm{mRNA}$ derived from blastocycts of preimplantation bovine embryo of groups treated with Boric acid.

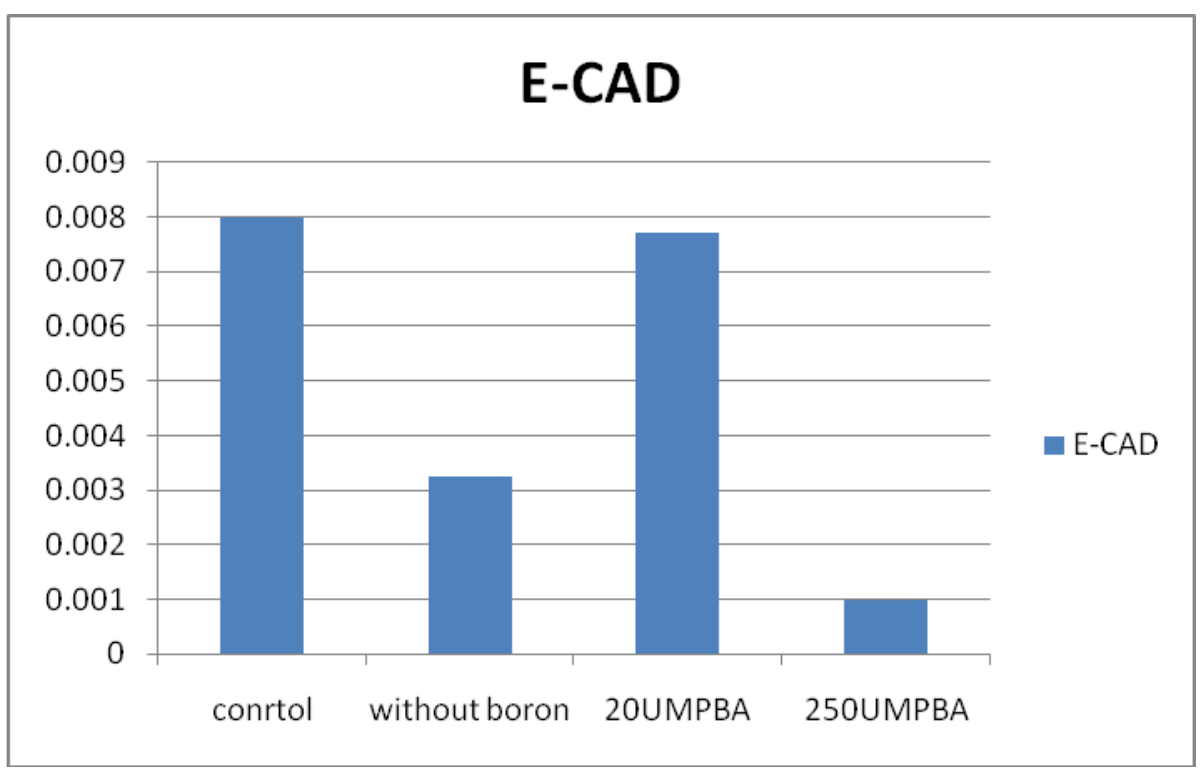

Fig.: (6) Relative expression of E-cadherin mRNA in blastocycts derived from blastocycts of preimplantation bovine embryo of groups treated with phenyl boron. 


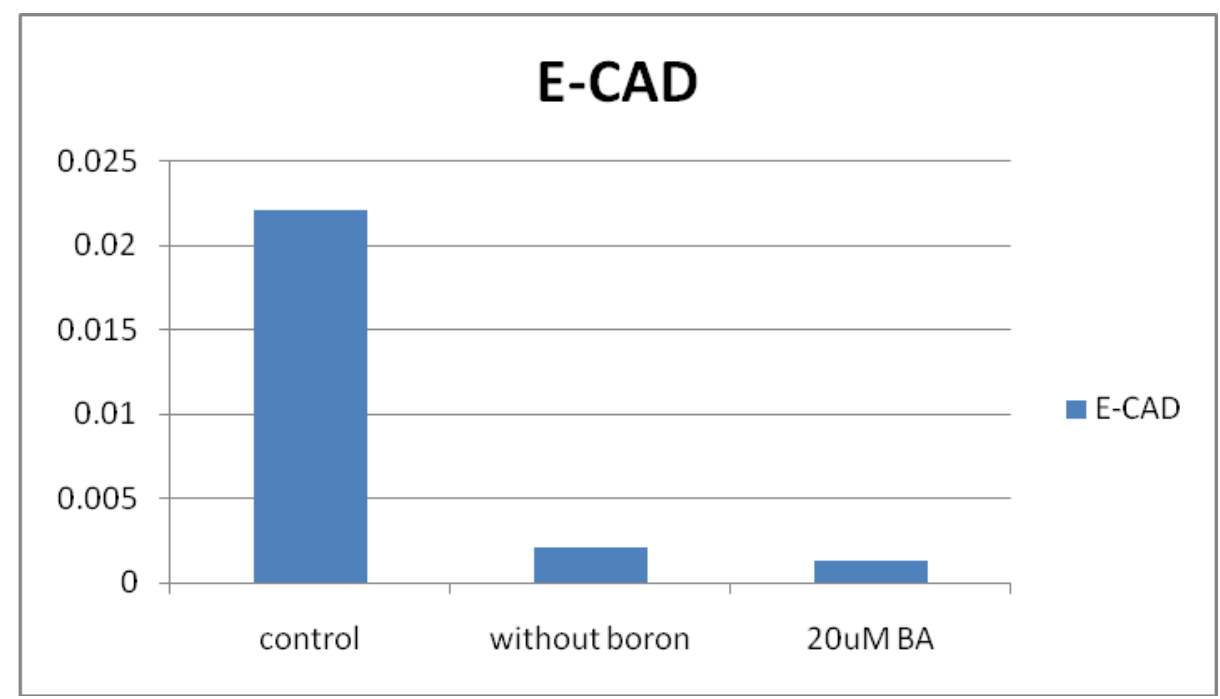

Fig.: (7) Relative expression of E-cadherin mRNA in blastocycts derived of preimplantation bovine embryo of groups treated with boric acid.

\section{Discussion}

Earlier reports showed that B was essential for at least for vertebrates embryonic development. When B deprivaion resulted in a high percentage of necrotic eggs and abnormal development of the gut in Xenopus laevis (Fort et al., 1999). The early stage of development is especially sensitive to B deficiency as described for mated zebrafish (Rowe et al. 1998 and Rowe and Eckhert, 1999) and the preimplantation mouse embryo (Lanoue et al. 1999).

The present results indicate that Phenyl boron improve the development of pre-implantation bovine embryo than the boric acid and increase expression of CX43mRNA and Ecadherin mRNA. In addition the absence of PB or BA decreased the development of the preimplantation bovine embryo(39.02 and 13.04 respectively compared with 47.37in control group).

According to Laoue, (1998) impaired embryonic differentiation and proliferation were observed only when embryos were exposed to high levels of boric acid (>2000microM), reflecting a very low level of toxicity of BA on early mouse embryonic development. Maternal exposure to the low B diet for 10,12, 1nd $16 \mathrm{wk}$ was associated with a reduction in blastocyst formation, a reduction in blastocyst cell number, and an increased number of degenerates. Collectively, these studies support the concept that B deficiency impairs early embryonic development in rodents.

According to Heindel et al (1994), boron causes significant increase in both the percentage of embryonic resorption and late fetal death of ratembryo. The percentage of malformed fetuses per litter and the percentage of litters containing at least one malformed fetus were increased at all doses studied. A variety of malformations was noted, including anomalies of the eyes, the central nervous system, the cardiovascular system, and the axial skeleton. They also suggested that boric acid treatment particularly in the high-dose was associated with significant adverse post implantation effects in mice. The most frequently observed malformations in the $1003 \mathrm{mg} / \mathrm{kg} /$ day boric acid treated litters were skeletal defects, particularly short rib XIII. Malformation were dose dependent as malformations were fewer in low $(248 \mathrm{mg} / \mathrm{kg} / \mathrm{day})-$ and $\mathrm{mid}$ dose $(452 \mathrm{mg} / \mathrm{kg} /$ day $)$ group than in the control group. In particular, the incidence of full or 


\section{Comparative Study on the Effects of.....}

rudimentary lumbar I rib(s) was less frequentl in fetuses of boric acid-treated mice.

The fact that BA react with hydroxyl groups is considered the key to understand boron functions. Bolanos et al., 2004 stated that "the primary role of boron in biological systems is stabilization of molecules with cisdiol groups, independently of their function" and "boron chemistry makes it a perfect candidate for atomic diester bridging". Whether the formation of two-sided complexes is imperative for boron's function(s) is still being debated. On the basis of the stability of known borate monoesters in aqueous systems and the distribution of cisdiol-binding sites in cells, it seems less likely that $\mathrm{B}$ monoesters play a relevant metabolic function. Chemical conditions in living systems do not favor monoester formation, and only di-esters could achieve stabilities high enough to be of physiological relevance. Using PBA as probes in plant experiments for B-binding ligands forming exclusively onesided esters makes it possible to search for those functions where $\mathrm{B}$ is required for crosslinking ligands with cis-hydroxyl groups as in RGII (Bassil et al., 2004).

At physiological $\mathrm{pH}, \mathrm{B}$ is present as uncharged boric acid which, combined with its relatively high lipid solubility (Raven 1980), allows rapid penetration of biological membranes, as demonstrated by Stangoulis et al. (2001) and Hayes and Reid (2004). Under conditions of adequate B nutrition, active uptake of environmental B would therefore seem unnecessary.

The present results indicated that the high dose of phenyl boron $(250 \mu \mathrm{M} / \mathrm{L})$ and absence of $\mathrm{PB}$ or BA decreased the development of zygotes and these may be attributed to decrease the expression of CX43and Ecadherin mRNA in blastocyctes of bovine embryo. This is according to Sullivan et al, 1993 whose suggested that $\mathrm{Cx} 43$ is a single copy gene that consists of two exons and one intron.

During murine preimplantation development functional gap junctions are first observed at compaction at the eight-cell stage (Lo and Gilula, 1979; McLachlin et al, 1983; Goodall and Johnson, 1984) and are necessary for the maintenance of compaction, and thus for subsequent blastocyst formation (Lee et al, 1987; Bevilacqua et al, 1989). Expression of E-cadherin in embryonic development is very early, at the two-cell stage [Larue et al., 1994 and Rietmacher $e t$ al., 1995]. Epithelial differentiation and polarization (processes fundamental to cell differentiation) occur early in ontogeny in the morula stage, when the embryo compacts and each cell polarizes along its apicobasal axis to generate an epithelial-like phenotype. Ecadherin plays an important role in the adhesion of the blastomeres, and early embryo's ability to compact [Fleming $\boldsymbol{e t}$ al., 1992]. E-cadherin is expressed in the membrane even before compaction of the morula occurs, is distributed in a non-polar manner, and does not exhibit adhesive function [Hyafil et al., 1980, and Vestweber\&, Kemler,1984]. The mechanism that renders E-cadherin function is unknown, but it does include phosphorylation of the protein [Sefton, et al., 1992]. Controlled epithelial-mesenchymal conversion is the most important exhibit of E-cadherin's function in development [Thiery, 2002]. Loss of epithelial adhesion and polarity causing mesenchymal cell morphology occurs during mesoderm formation. Rietmacher and coworkers [Rietmacher et al., 1995] introduced a targeted mutation in mouse embryonal stem cells and generated a mouse without Ecadherin sequences essential for $\mathrm{Ca}^{2+}$ binding and for adhesive function. Heterozygous mutant animals were normal and fertile. In vitro, they were able to form normal blastocysts with normal blastocoels that consequently expanded. On the other hand, the homozygous E-cadherin -/- embryos showed severe abnormalities before implantation which included failure to maintain a polarized and compacted state and also failure to form a trophectoderm epithelium making this mutation lethal. The initial compaction that was observed in -/- embryos is probably due to the presence of E-cadherin proteins from maternal sources [Sefton, et al., 1992].

Investigation of zebrafish E-cadherin expression during early embryogenesis confirmed observed expression in 
blastomeres, but also led to the detection of a protein expressed in the anterior mesoderm during gastrulation and development epithelial structures [Babb, et al., 2001]. Cadherin mediated adhesion is a dynamic process that is regulated by several signal transduction pathways. There is also evidence

\section{References}

1- Babb SG, Barnett J, Doedens AL, Cobb N, Liu Q, Sorkin BC, Yelick PC. Raymond PA. and Marrs JA(2001): Zebrafish E-cadherin: Expression during early embryogenesis and regulation during brain development. Dev Dyn, 221:231-237.

2- Barth AI, Nathke IS, and Nelson WJ (1997): Cadherins, catenins and APC protein: interplay between cytoskeletal complexes and signaling pathways. Curr Opin Cell Biol, 9:683-690.

3- Bassett PL. (1990). A critical evaluation of the available measurements for the stable isotopes of boron. Appl Geochem.; 5:541-554.

4- Bassil, E., Hu, H. N., and Brown, P. H. (2004): Use of phenylboronic acids to investigate boron function in plants. Possible role of boron in transvacuolar cytoplasmic strands and cell-to-wall adhesion. Plant Physiol. 136: 3383-3395.

5- Beyer EC, Paul DL and Goodenough DA (1987): Connexin43, a protein from rat heart homologous to gap junction protein from liver J. of Cell Biol. 105: 2621-2629.

6- Bolanos, L., Lukaszewski, K., Bonilla, I., and Blevins, D. (2004): Whyboron? Plant Physiol. Biochem. 42: 907-912.

7- Bruzzone R, White TW and Goodenough DA (1996a)The cellular internet: on-line with connexins. BioEssays 18: 709-718.

8- Bruzzone R, White TW \& Paul DL (1996b) connections with connexins: the molecular basis of direct intercellular signaling. European J. of Biochem. $238: 1-27$.

9- Butterweck A, Gergs U, Elfgang C, Willecke K and Traub O(1994): Immunochemical characterization of the gap junction protein connexin45 in mouse kidney and transfected human HeLa cells. J. of Membrane Biol. 141: 247256.

10- Delorme B, Dahl E, Jarry-Guichard T, Briand J-P, Willecke K, Gros D and Theveniau-Ruissy M (1997): Expression pattern of connexin gene products at the early developmental stages of the mouse cardiovascular system. Circulation Res. 81: 423-437.

11- Douglas J F, Enos L S, Philip L S, Murray F J and. Keen LC (1999): Chronic feeding of a low boron diet adversely affects reproduction and development in Xenopus laevis J. of Nutr.129:2055-2060. that cadherins are not only targets for signaling pathways that regulate adhesion, but may themselves send signals that regulate basic cellular processes, such as migration, proliferation, apoptosis and cell differentiation [Hulsken, et al., 199;Barth, et al.,1997and Morin et al., 1997].

12- $\quad$ Fogg, T. R. \& Duce R. A. (1985) Boron in the troposhere: distribution and fluxes. J. Geophys Res. 90(D2): 3781-3792.

13- Fort D J., Stover E L., Strong P L., Murray F J. and Keen C L. (1999): Chronic feeding of a low boron diet adversely affects reproduction and development in Xenopus laevis. J. Nutr. 129, 2055-2060.

14- Gumbiner BM. (1996): Cell adhesion: The molecular basis of tissue architecture and morphogenesis. Cell 84:345-357.

15- Hayes, J.E. and Reid, R.J. (2004) Boron tolerance in barley is mediated by efflux of $\mathrm{B}$ from the roots. Plant Physiol. 136: 3376-3382.

16- Heindel JJ, Price CJ, and Schwetz BA. (1994). The developmental toxicity of boric acid in rats, mice, and rabbits. Environ Health Perspect 102: 107-112

17- Hulsken J, Birchmeier W, and Behrens J(1994): E-cadherin and APC compete for the interaction with $\boldsymbol{\beta}$-catenin and the cytoskeleton. $\mathrm{J}$ Cell Biol, 127:2061-2069.

18- Hunt C D. (1994): The biochemical effects of physiologic amounts of dietary boron in animal nutritional models. Environ. Health Perspect. 102:35-43.

19- Hunt C D. (1996): Dietary boron deficiency and supplementation. Trace Elements in Laboratory Rodents pp 229-253 Watson R.R.ed. CRC Press Boca Raton, FL.

20- Hyafil F, Morello D, Babinet C, and Jacob F (1980): A cell surface glycoprotein involved in the compaction of embryonal carcinoma cells and cleavage stage embryos. Cell 21:927-934

21- Lampugnani M.G. and Djana E. (1997) Interendothelial junctions : structure, signalling and functional roles. Curr. Opin. Cell Biol. 9: 674-682.

22- Lanoue, L., Taubeneck, M.W., Muniz, J., Hanna, L.A., Strong, P.L., Murray, F.J., Nielsen, F.H., Hunt, C.D., and Keen, C.L. (1998): Assessing the effects of low boron diets on embryonic and fetal development in rodents using in vitro and in vivo model systems. Biol. Trace Elem. Res. 66, 271-298

23- Lanoue L ,. Strong P L ,. Keen C L(1999): Adverse effects of a low boron environment on the preimplantation development of mouse embryos in vitro. J. of Trace Elements in Exper. Med.: $235-250$ 
24- Larue L, Ohsugi M, Hirchenhain J, and Kemler R (1994): E-cadherin null mutant embryos fail to form a trophectoderm epithelium. Proc Natl Acad Sci USA 91:8263-8267.

25- Libes, S. M. (1992) An Introduction to marine biogeochemistry. John Wiley \& Sons, New York.

26- Lonergan P, Khatir H, Piumi F, Rieger D, Humblot P, and Boland MP. (1999): Effect of time interval from insemination to first cleavage on the developmental characteristics, sex and pregnancy rates following transfer of bovine preimplantation embryos. J Reprod Fertil; 117: 159-167.

27- Lonergan P, Rizos D, Gutierrez-Adan A, Moreira PM, Pintado B, de la Fuente J, and Boland MP. (2003a). Temporal divergence in the pattern of messenger RNA expression in bovine embryos cultured from the zygote to blastocyst stage in vitro or in vivo. Biol Reprod. 69: 14241431.

28- Lonergan P, Rizos D, Kanka J, Nemcova L, Mbaye AM, Kingston M,Wade M, Duffy $P$ and Boland MP.( 2003b). Temporal sensitivity of bovineembryos to culture environment after fertilization and the implicationsfor blastocyst quality. Reproduction 126:337-346.

29- Makowski L, Casper DLD, Phillips WC and Goodenough DA (1977) Gap junction structures. II. Analysis of the x-ray diffraction data. J. of Cell Biol. 74 629-645.

30- Memili E, Dominko T and First NL.(1998): Onset of transcription in bovine oocytes and preimplantation embryos. Mol Reprod Dev; 51:3641.

31- Morin PJ, Sparks AB, Korinek V, Barker N, Clevers H, Vogelstein B and Kinzler KW(1997): Activation of $\boldsymbol{\beta}$-catenin-Tcf signaling in colon cancer by mutations in $\boldsymbol{\beta}$-catenin or APC. Science, 275:1787-1790.

32- Nemodruk, A. A. and Karalova, Z. K. (1969) Analytical Chemistry of Boron. Ann.ArborHumphrey Science Publishers, London.

33- Nielsen F H. (1994); Biochemical and physiological consequences of boron deprivation in humans. Environ. Health Perspect. 102:59-63.

34- Nielsen F H. (1996) Evidence for the nutritional essentiality of boron. J. Trace Elem. Exp. Med. 9: 215-229.

35- Nicholson B, Dermietzel R, Teplow D, Traub O, Willecke K and Revel J-P (1987): Two homologous protein components of hepatic gap junctions. Nature 329: 732-734.

36- Parrish JJ, Susko-Parrish JL, Winer MA and First NL (1988): Capacitation of bovine sperm by heparin. Biol. of Reprod. $38: 1171-11$.

37- Rietmacher D, Brinkmann V, and Birchmeier CA (1995): Targeted mutation in the mouse Ecadherin gene results in defective preimplantation development. Proc Natl Acad Sci USA 92:855859.

38- Rizos D, Lonergan P, Boland MP, ArroyoGarcia R, Pintado B, de la Fuente J and
Gutierrez-Adan A. (2002a). Analysis of differential messengerRNAexpression between bovine blastocysts produced in different culture systems: Implications for blastocyst quality. Biol Reprod 66:589-595.

39- Rizos D, Ward F, Duffy P, Boland MP and Lonergan P. (2002b). Consequences of bovine oocyte maturation, fertilization or early embryo development in vitro versus in vivo: Implications for blastocyst yield and blastocyst quality. Mol Reprod Dev 61:234-248.

40- Rizos D, Gutierrez-Adan A, Perez-Garnelo S, De La Fuente J, Boland MP, and Lonergan P. (2003). Bovine embryo culture in the presence of serum: Implication for blastocyst development, crytolerance, and messenger RNA expression. Biol Reprod 68:236-243.

41- Robert C, McGraw S, Massicotte L, Pravetoni M, Gandolfi F and Sirard MA, (2002): Quantification of housekeeping transcript levels during the development of bovine preimplantation embryos. Biol Reprod 67, 14651472.

42- Rosenkrans CF and First NL,(1994): Effect of free amino acids and vitamins on cleavage and developmental rate of bovine zygotes in vitro. $\mathbf{J}$ Anim Sci 72, 434-437.

43- Rowe R I, Bouzan C, Nabili S and. Eckhert C D.(1998) The response of trout and zebrafish embryos to low and high boron concentrations is U-shaped. Biol. Trace Element Res. 66: 261-270.

44- Rowe, R I , Eckhert, C. D. (1999): Boron is required for zebrafish embryogenesis. J. Exp. Biol. 202:1649-1654.

45- Sa'ez JC, Martinez AD Brañes MC and Gonza'lez HE (1998): Regulation of gap junctions by protein phosphorylation. Braz. J. of Med. and Biol. Res. 31: 593-600.

46- Schuetz E G., Beck W T. and Schuetz J D. (1996): Mol. Pharmacol. 49, 311.

47- Schuetz and E. G and Schinkel A. H. (1999): J. Biochem. Mol. Toxicol. 13, 219.

48- Sefton M, Johnson M., Clayton L(1992): Synthesis and phosphorylation of uvomorulin during mouse early development. Develo. (Cambridge, UK), 115:313-318.

49- Stagg RB and Fletcher WH (1990): The hormone-induced regulation of contactdependent cell-cell communication by phosphorylation. Endocrine Reviews 11 302325.

50- Stangoulis, J.C.R., Reid, R.J., Brown, P.H. and Graham, R.D. (2001): Kinetic analysis of boron transport. Chara. Planta 213: 142-146.

51- Stevenson, R. W. (1986): Cycles of Soil. John Wiley and Sons, New York.

52- Tesfaye D, Ponsuksili S, Wimmers K, Gilles M, Schellander K (2003): Identification and quantification of differentially expressed transcripts in in vitro-produced bovine preimplantation stage embryos. Mol. Reprod. Dev. 66, 105-114. 
53- Tesfaye D, Ponsuksili S, Wimmers K, Gilles M, Schellander K, (2004): A comparative expression analysis of gene transcripts in post fertilization developmental stages of bovine embryos produced in vitro or in vivo. Reprod Dom Anim 39, 396404.

54- Tesfaye D, Lonergan P, Hoelker M, Rings F, Nganvongpanit K, Havlicek V, Beseenfelder U, Jennen D, Tholen E, and Schellander K (2007): Suppression of Connexin 43 and E-Cadherin transcripts in in-vitro derived bovine embryos following culture in-vitro or in-vivo in the homologous bovine oviduct. Mol. Reprod. and Devel. 74:978-988.

55- Thiery JP.(2002): Epithelial-mesenchymal transitions in tumour progression. Nat Rev Cancer, 2:442-454.
56- Vestweber D, Kemler R(1984): Rabbit antiserum against a purified surface glycoprotein decompacts mouse preimplantation embryos and reacts with specific adult tissues. Exp Cell Res 152:169-178.

57- Wacher V J., Wu C Y. and Benet L Z. (1995): Mol. Carcinog. 13, 129.

58- Yoshioka K and Kamomae H (1996) Recombinant human activin A stimulates development of bovine one-cell embryos matured and fertilized in vitro. Mol. Reprod. and Devel. 45 151-156.

59- Zimmermann JW and Schultz RM (1994): Analysis of gene expression in thepreimplantation mouse embryo: use of mRNA differential display. Proc. the Nat. Acad. of Sci. USA 91 5456-5460. 


\section{Comparative Study on the Effects of.....}

التأثيرات المختلفة للبورون كفنيل بورون او حمض البوريك على نمو اجنة البقر قبل انغماسها فى جدار

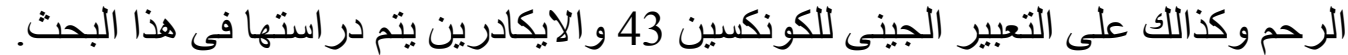

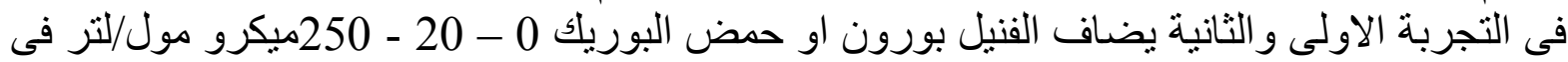

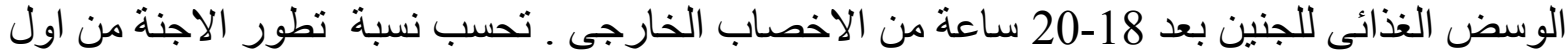

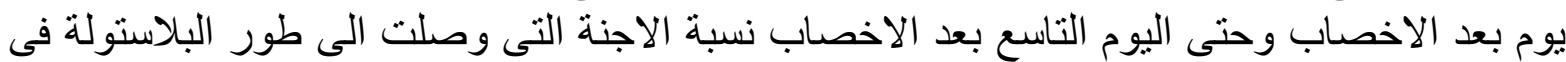

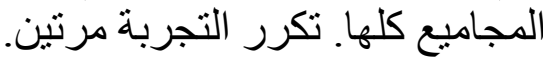

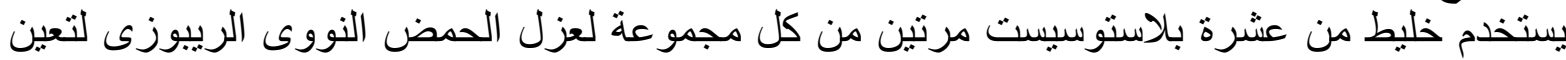

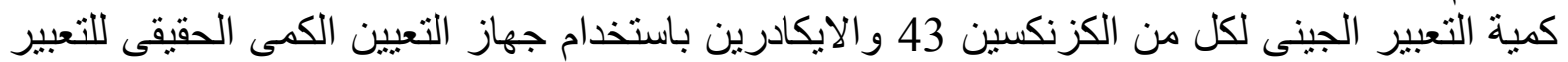
الجينى فى الحمض النجير الجنووى الريبيوزى الكرنكين

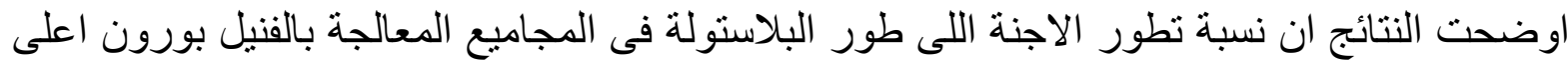

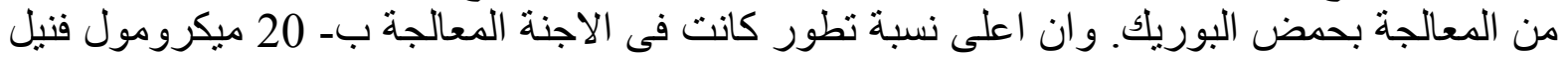

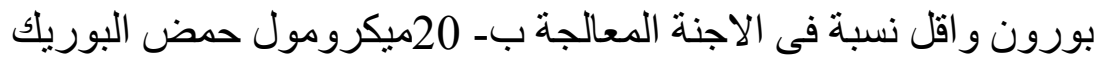

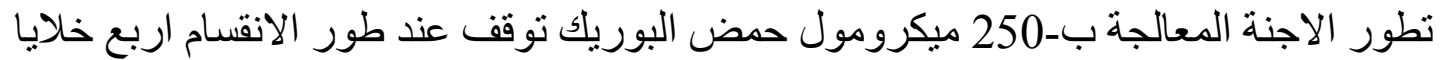

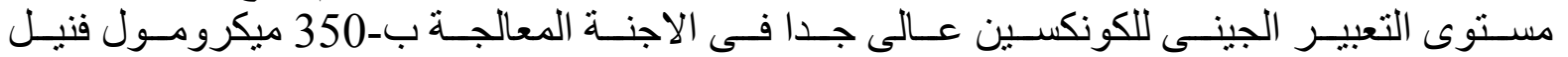

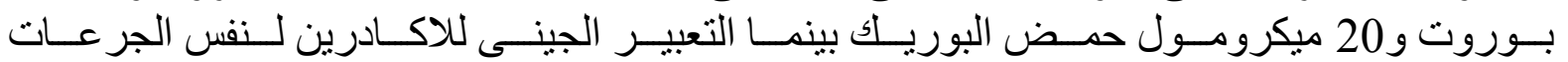

